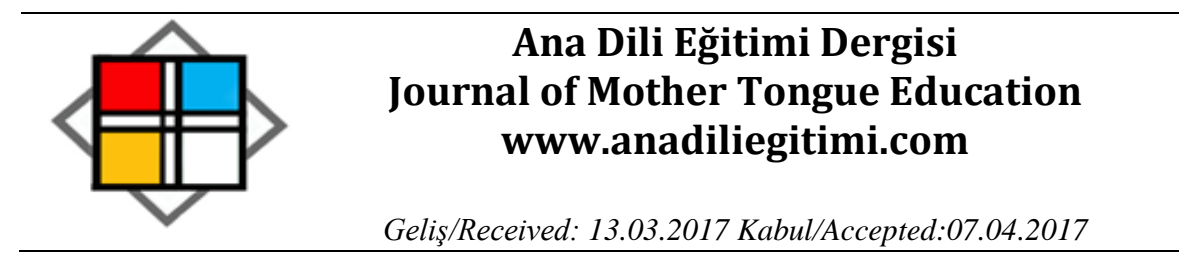

\title{
Yaratıcı Yazma ve Toplumsal Cinsiyet
}

\author{
Erkan ÇER ${ }^{*}$
}

Öz

Bu çalışma, yaratıcı yazma sürecinde öğrencilerin toplumsal cinsiyet algılarını ortaya çıkarmayı amaçlamaktadır. Böylelikle öğrencilerin yazılarının toplumsal cinsiyet ile olan ilişkisi ortaya çıkartılmaya çalışılacaktır. Bu amaç doğrultusunda, nitel bir araştırma deseni kullanılarak araştırmacı tarafından verilen karakterler aracılı̆ıyla öğrencilerin yazılarındaki toplumsal cinsiyet algıları incelenmiştir. Araştırmanın katılımcılarını uygun örnekleme yoluyla seçilmiş olan ve Amasya ilinde üniversite, ortaöğretim ve ilköğretim sürecinde eğitimlerini sürdürmekte olan 57 öğrenci ile 5 yetişkin oluşturmaktadır. Araştırmanın farklı yaş ve düzeylerdeki katılımcılarla yürütülmesinin nedeni ise, her yaş ve düzeyde yaratıcı yazma ile ortaya çıkabilecek toplumsal cinsiyet algılarını ortaya çıkartıp gruplar arasında karşılaştırma yapabilmektir. Bu çalışmada, tek sorudan oluşan bir anket aracılığıyla katılımcılardan içerisinde prens, prenses, cadı ve ejderhanın olduğu bir masal yazmaları istenmiştir. Daha sonra, katılımcıların prens, prenses, cadı ve ejderhayı nasıl betimlendiğine ilişkin yazdıkları masallara içerik analizi uygulanmıştır. İçerik analizinde ortaya çıkan izlekler (tema) sınıflandırılmış ve daha sonra bu sınıflandırmalar frekans ve yüzdeler aracılığıyla rapor edilmiştir. Sonuç olarak, bu çalışmada, farklı yaş ve cinsiyette bulunan öğrenci ve yetişkinlerin yaratıcı yazılarında verilen karakterlere yönelik yansıttıkları toplumsal cinsiyet anlayışlarının birbirlerine benzer oldukları ortaya çıkartılmıştır.

Anahtar Sözcükler: Yaratıcı Yazma, Toplumsal Cinsiyet, Öğrenci, Yetişkin

\section{Creative Writing and Social Gender}

\begin{abstract}
The study aimed to reveal learners' gender perceptions in the process of creative writing. This way, revealing the relationship between the students' writings and social gender was intended to be identified. In accord with this aim, using a qualitative research design, through the characters provided by the researcher, the perceptions of social gender in the participants' writings were analyzed. The participants, chosen by convenience sampling, were 57 students, who were studying at university, secondary and primary schools in Amasya and 5 adults. The reason why the research was conducted with the participants who were at different age and education levels was that it would be possible to make comparisons of the perceptions of gender which might appear by creative writing at every age and developmental level. Through a given one-item questionnaire, the participants were asked to write a tale which consisted of a prince, a princess, a witch, and a dragon. Afterwards, content analysis was used on those tales to find out how the participants described the prince, princess, witch, and the dragon. The themes that emerged were classified first, and their frequencies and percentages were reported. The results showed that the gender perceptions of the students and the adults, who were at different age levels, for the given characters in their creative writings were similar.
\end{abstract}

Keywords: Creating writing, Social Gender, Students, Adults

\footnotetext{
${ }^{*}$ Yrd. Doç. Dr, Amasya Üniversitesi, Eğitim Fakültesi, Sosyal Bilimler ve Türkçe Eğitimi Bölümü, Amasya. e-posta: erkan.cer@gmail.com
} 


\section{Giriş}

Toplumsal cinsiyet ile çocukların dili kullanma biçimleri arasında güçlü bir ilişki vardır (Davies, 1993). Çünkü dil, toplumsal cinsiyet rollerinin onaylandığı kültürlerde sosyalleşen çocukların kullandıkları başlıca araçlarından biridir. Çocuklar, kültür içinde dili kullanmayı öğrendikleri zaman, aynı zamanda o kültürün kadın ve erkeğe yüklediği kültürel rolleri de sezinlerler. Bununla birlikte, çocuklar, bu rolleri o kadar çabuk sezinler ki kız ve erkek olarak kendilerini birçok biçimde tanımlayabilirler. Örnek olarak, çocuklar, uygun gördükleri akran gruplarının üyeliğini kazanmak için konuşma ve davranış biçimlerini gruplarda yer alan kız ve erkek cinsiyetlerinin durumlarına göre değiştirebilirler (Peterson, 2001). Bu durum, çocukların grup tarafından önemsenmek ve onaylanmak için toplumsal cinsiyetçi kimliklere bürünebileceğini göstermektedir. Bununla birlikte, çocuklar, bir kurgu içerisinde öyküleyici ya da yaratıcı metinler ortaya koyarken metni oluşturan olay, durum, yer ve karakterleri toplumsal cinsiyetçi bir biçimde kalıplaştırabilirler (Gray-Schlegel ve Gray-Schlegel, 1995). Bütün bu yönleriyle toplumsal cinsiyet, çocuk ve onun dünyasını oluşturan değişkenler üzerinde baskın toplumsal ve kültürel yapının bir sonucu olarak kadın ve erkeğe yönelik cinsiyet rollerini basmakalıp bir biçimde duyumsatabilir.

Birçok dilde çocuklar tarafından oluşturulan öyküleyici ve yaratıcı yazılar, kültürel çevrenin yansımasını oluştururlar (Peterson, 2001). Bu yönüyle yaratıcı yazma, dış dünyadan elde edilen izlenimlerin farklı bir anlatımla ortaya konması olduğuna göre (Maltepe, 2006), yaratıcı yazma sürecinde çocuklar, duygu ve düşüncelerini belli bir kurgu içinde anlatırken toplumsal cinsiyetçi rollerini gösterme eğiliminde olabilirler (Peterson, 2001). Çünkü toplumun ortak bilinçaltında yer edinmiş tektipleştirilmiş toplumsal cinsiyetçi roller, çocukların dil, davranış, inanç, tutum ve düşüncelerini biçimlendirebilir. Bu yönüyle, toplumsal cinsiyet, sonradan öğrenilen bir niteliktir ve kadın ve erkeğe yönelik olarak kabul edilen ilişki ve davranışların sürekli olarak yeniden doğrulanmasıyla gelişmektedir (Cameron, 1999). Böylelikle, çocuklar, yaratıcı yazılar ortaya koyarken oluşturdukları karakterlere, olaylara, durumlara ya da kurgunun kendisine basmakalıp toplumsal cinsiyetçi rolleri yükleyebilir ve kendisini diğer cinsiyetlerden tamamen ayrı gösterebilir. Oysa çocuklar, yazılarını oluştururken gerçek ya da düşsel karakterlere cinsiyetlerin kendisini değil toplum tarafından belirlenmiş basmakalıp cinsiyetçi rolleri yansıtmaktadırlar. Örnek olarak, ilköğretim öğrencilerin yazıları ile toplumsal cinsiyet üzerine yapılan araştırmalara bakıldığında, öğrencilerin ortaya çıkardığı yazılarda basmakalıp toplumsal cinsiyet ile ilgili rolleri kanıksadığı belirlenmiştir. Bu rollerde, kız çocukları daha çok duygusal ve toplum yanlısı rollerdeyken; erkek çocukları, daha çok atılgan, girişken ve saldırgan davranışlar ile gerilim dolu ve tehlikeli eylemlerde olduğu görülmüştür (Fleming, 1995; Gray-Schlegel ve Gray-Schlegel, 1995; Kamler, 1993; McAuliffe, 1994; Trepanier ve Romatowski, 1985; Trepanier-Street ve Romatowski, 1991). Bununla birlikte, yapılan araştırmalarda, 
öğrencilerin basmakalıp toplumsal cinsiyetçi farklılıkları yazma sırasında seçtikleri konulara da yansıttıkları görülmektedir. Bu araştırmalarda ise, kız öğrenciler daha çok ev işleri ile ilgili; erkek öğrenciler ise, kahramanlık, şiddet ve dış dünya ile ilgili konular üzerine yazmışlardır (Buxton, 2011; Clark, 1995; Spear, 1989; Shuman, 1995; Tyre, 2008). Aynı zamanda, birçok araştırma, çocukların okumak için seçilen uyaranlarla birlikte yazınsal türlere de toplumsal cinsiyetçi farklılıkları yansıttıklarını ortaya koymaktadır (White, 1990; Millard, 1997).

Bu araştırmada, çocukların ortaya koyduğu yaratıcı yazılar ile toplumsal cinsiyet arasındaki ilişki kültürel bağlamda ele alınmıştır. Birçok farklı kültürde, çocukların yazdıkları görsel ve dilsel metinlerde (Gray-Schlegel ve Gray-Schlegel, 1995; Kamler, 1993; McAuliffe, 1994) toplumsal cinsiyetçi rollerin olduğu görülürken Türk kültüründe bu tür araştırmalar çok fazla yapılmamıştır. Bu durum, Türk toplumsal ve kültürel yapı içerisinde yetişen çocukların yaratıcı yazılar ortaya koyarken bile toplumsal cinsiyetçi öğeleri yazılarına yansıtıp yansıtılmadığının belirlenmesini geciktirmiştir. Bu yönüyle, bu araştırma, hem böyle bir açığı kapatarak Türk kültüründe çocukların yazdıkları yazılardaki toplumsal cinsiyetçi durumların başka kültürlerde ortaya çıkan durumlarla benzer özellikler taşıyıp taşımadığını ortaya çıkartacak hem de çocukların kadın ve erkek cinsiyetlerini hangi tür rollerde betimlediği belirlenecektir. Bu bakımdan, öncelikle konunun daha iyi anlaşılabilmesi için yaratıcı yazma ve yaratıcı düşünme ile toplumsal cinsiyet değişkenlerinin açıklanması gerekmektedir.

\section{Yaratıcı Yazma ve Yaratıcı Düşünme}

Yaratıcı yazma; var olan bilgileri, kavramları, olayları, bellekteki sözleri, görüntüleri, düşleri yeniden kurgulayarak ve birbirleriyle ilişkilendirerek özgür bir biçimde iş birliği ya da bireysel olarak ortaya yeni bir yazı koyma etkinliği (Arthur ve Zell, 1996; Brookes ve Marshall, 2004; Graham ve Perin, 2007; Ramet, 2007; Vass, Littleton, Miell ve Jones, 2008), insanın kendi olabilmesi, başkalarından özgür olarak kendine özgü olanı keşfedebilmesi, duyu algılarını devindirerek görebilmesi, işitme, duyumsama yetilerini geliştirmesi, kısaca kendini ve çevresini algılayıp ifade edebilmesi (İpşiroğlu, 2006), birçok düşünce ve düş arasından daha önce kurulmamış, ilginç ve akıcı ilişkiler kurabilmesi (Temizkan, 2010; Thomson, 2013), var olan bilgileri, kavramları, olayları, bellekteki sesleri, görüntüleri, düşleri yeniden kurgulayarak ve birbirleriyle ilişkilendirerek ortaya yeni bir şiir, öykü, masal, deneme ya da roman koyma becerisidir (Güleryüz, 2006; Oral, 2003).

Yaratıcı yazma, dilin ve düşüncenin etkili kullanımını ortaya çıkartan değişkenleri içinde barındırır (Applebee, 2001). Alışılmışın dışına çıkarak herkesten farklı düşünceler ortaya koyma, özgünlüğü yakalama, düş gücüyle kanıksanmış durumları yansıtmama, bir probleme var olan çözüm yollarının dışında çözüm üretme ve düşünceyi üst düzey devindirme yaratıcı yazmanın başat değişkenleridir. Çünkü dilsel, düşünsel ve duygusal deneyimlerin bilişte özgün bir biçimde yeniden 
yaratılması, yaratıcı yazmanın felsefesini oluşturmaktadır (Sharples, 1999). Bu yönüyle, çocukların dilin yaratıcı anlatım olanaklarıyla yeni ve özgün düşünceler oluşturabilmesi ve derin çağrışımlar yaratabilen sözcüklerle de duygularını anlatabilmesi, yaratıcı yazma becerisinin geliştirilmesi gerektiğini ortaya koymaktadır. Daha farklı bir anlatımla, çocukların okuma kültürü içinde olabilmeleri, onların erken dönemden başlayarak dilin yazılı simgeleriyle kuracakları etkileşimin niteliğini geliştirebilir. Böyle bir etkileşim, çocukları, yazma sürecinde, sözcüklere farklı anlamlar yüklemesini, olayı oluşturan çatışma ve gerilim anlarını özgün bir biçimde kurgulamasını, karakterlerin özgün ilişki ve davranışlarla ele almasını sağlayabilir.

Yaratıcı yazılarla oluşturulan kurguda; yeni bir dünya yaratılır, insanlar değişebilir, onlara yeni bir yaşam sunulabilir (Özdemir ve Binyazar, 1979; Sever, 2004; Stuart, 2005; Morley, 2007; Myers, 1993; Nickerson, Perkins ve Smith, 1985). Çünkü yaratıclık, bilinen kavramlarla yeni ve özgün ilişkiler, bağıntılar ve bağlantılar kurmaktır (Yıldıım, 2003). Bu yönüyle, yaratıcı düşünme, düş gücünü gerektirir ve insanı pek çok olası yanıta, çözüme ve düşünceye götürür (Üstündağ, 2004). Daha ayrıntılı bir açıklamayla, yaratıcılık içerisinde, düş gücünü, merakı, alışımışın dışında düşünmeyi, üretkenliği, problem çözmeyi ve özgünlüğü (Sharp, 2004; Woolf ve Belloli, 2005), keşfetmeyi, araştırmayı, incelemeyi ve değerlendirmeyi (Mayesky, 1995), düşüncede esnekliği, özgünlüğü ve duyarlığı barındııır (Adıgüzel, 2010). Bununla birlikte yaratıcılık, çocuğa, yeni bir şey yapmanın heyecanını yaşatır (Woolf ve Belloni, 2005). Bu yönüyle, yaratma süreci, çocuğun başarma dürtüsünü güçlendirir (Yıldırım, 2003). Bu süreçte çocuk, yaptığı işe önem verir; bu durum çocuğun kendine olan saygısını arttırır (Striker, 2005). Bütün bu yönleriyle, yaratıcı süreçte yer alan sezgi, imgelem, uslamlama, deneme, araştırma, sınama, bulma, kalıplardan kurtulma, yeniden kurma gibi birtakım yeti, olgu ve niteliklerle de çocuklar etkin bir biçimde duygu ve düşüncelerini devindirerek becerilerini geliştirir (San, 2008).

Eğitim ve öğretim süreçlerinde, hem yaratıcılı̆ı̆n hem de yazma becerisinin sürekli kullanılıp işlenerek ortaya çıkarılması ve geliştirilmesi gerekir. Böylelikle öğrencilerin istenilen düzeyde yaratıcı yazma becerilerinin geliştirilmesi, onların dış dünyayı algılamaları ve anlatmalarında kendi görüş, düşünce ve düş güçlerini kullanmaları gerektiğini ortaya çıkartır. Yani, öğrencilerin duyuları aracılığıyla dış dünyayı algılamaları, ayrıntıların farkında olmaları ve bu ayrıntıları bilişlerinde canlandırmaları, onları yaratıcı yazmada özgünlüğe ulaştırabilir (Demir, 2012). Bu yönüyle yaratıcı yazma, düş gücünün ürünü olarak görülmelidir. Düş gücü, yaratmayı, yaratıcılığın doyum gücüne, gelecekle ilgili yorum yapılmasına ve diğerlerinin yerine bireyin kendini koymasına olanak tanır. Böylelikle çocuklar, bu yazma biçimiyle, kendileri ve çocuklar için ideal bir dünya yaratırlar (Maltepe, 2006). Bu bakımdan, çocukların düş güçlerini geliştirmek, açık fikirli olmalarına ve kendi düşüncelerini alışımışın dışında 
ifade edebilmelerine olanak tanımak, insanı, yaşamı ve doğayı tanımalarını sağlamak yaratıcı yazmanın işlevleri arasındadır.

\section{Yaratıcı Yazma ve Toplumsal Cinsiyet}

Cinsiyet, kadın ve erkek olmanın biyolojik yönüyken; toplumsal cinsiyet, sosyal ve toplumsal yönüdür (Winstead, Derlega ve Unger, 1999). Yani, toplumsal cinsiyet, biyolojik ayrımın sosyal olarak yorumlanmasıdır. Bunun anlamı, toplumsal cinsiyetin biyolojik cinsiyet farklılıklarından ayrı olarak kadın ve erkeğin toplumsal olarak yapılandırılmış kimliği olmasıdır (Beasley, 2005). Bu kimlik, çocukları erken dönemden başlayarak aynı cinsiyet gruplarıyla etkileşimlerinin bir sonucu olarak davranışlarını basmakalıp bir biçimde biçimlendirmeye başlar (Fabes ve Eisenberg, 1996; Serbin, Moller, Gulko, Powlishta ve Colburne, 1994). Böylelikle, kız ve erkek çocukları, sosyal etkileşimlerinin bir sonucu olarak farklııklarını dışavururlar (Maccoby, 1990). Daha açık bir biçimde, toplumsal ve kültürel olarak, erkek çocukları yarışmacı, güçlü ve iddialı olmayı; kız çocukları ise yardımsever, duygusal ve ilişki içinde olmayı öğrenmektedirler (Leaper ve Smith, 2004).

Yaratıcı yazma sürecinde, çocuklar kurmaca bir dünyada özgün betimlemeler yaparken toplumsal cinsiyetçi karakterler yaratabilir ya da olay ve durumlara basmakalıp cinsiyetçi roller yükleyebilirler. Çünkü çocuklar, sonradan öğrendikleri basmakalıp cinsiyet rollerini erken dönemden başlayarak davranışlarına, düşüncelerine ve dilsel becerilerine yansıtırlar (Russell, Hart, Robinson ve Olsen, 2003). Bununla birlikte, toplumsal cinsiyet, kadın ve erkeğe yönelik olarak uygun bir biçimde görünmek olduğuna göre, çocuklar, aralarında örtüşen ya da birinden ötekine geçen yönlerin ya çok az olduğu ya da hiç olmadığı cinsiyete yönelik durumları yansıtma eğilimde oldukları için (Davies, 1993), yazma sırasında, kadın ve erkeğe yüklenen kalıplaşmış rolleri açık ya da kapalı bir biçimde anlatabilirler. Çünkü toplumsal cinsiyet, çocukların uzun süreli belleklerinde yerleşik hâle geldikten sonra görünmeyen bir güç olarak temsil edilir ve algıyı açık ve kolay bir biçimde etkileyebilir. Bununla birlikte, toplumsal cinsiyet, farklı rol ve etkinliklerle kız ve erkek çocuklarını biçimlendirerek bilgi ve davranış düzeylerinin belirlenmesine yol açabilir (Croft, Schmader, Block ve Baron, 2013; Steele, Spencer ve Aronson, 2002).

Dil aracılığıyla çocuklarda, toplumsal cinsiyet rollerin gelişmesi hızlı olmuştur (Martin ve Ruble, 2004; Bigler ve Liben, 2006). Çünkü dil, toplumun kültürünü ve değerlerini yansıtan güçlü bir araçtır (Hellinger ve Bufimann, 2015; Kavcar, Oğuzkan ve Aksoy, 2011). Oysa yaratıcı yazma, kurmaca bir gerçekliğin yaratıcı bir biçimde yazı yoluyla somutlanması olduğuna göre (Llosa, 2010), bu gerçekliği oluşturan tüm öğelerin özgün olması gerekmektedir (McVey, 2008; Morley, 2007). Yani, toplumun kalıplamış değerlerinden farklı bir biçimde, sözcüklerin ve anlamın yerleşik özelliklerinin 
dışında kullanılması gerekir (Göktürk, 1997). Böylelikle, duygu ve düşünceler alışılmışın dışında anlatılarak, yaratıcı eylem ve davranışlar ortaya çıkabilir. Oysa kalıp düşüncelerle, geleneksel yargılarla, emir ve öğütlerle, tek doğrunun olduğu iletilerle, sorgulamaya izin vermeyen yaklaşımlarla ve basmakalıp toplumsal cinsiyetçi rollerle yaratıcı eylem ve davranışlar geliştirilemeyebilir (Çer, 2016). Bu yönüyle, çocuğun yazılı anlatımla oluşturduğu dilinin bu özelliklerden arındırılması gerekir.

Yaşam boyunca, yetişkinlerin aynı cinsiyet gruplarıyla iş birliği içinde olmaları (Mehta ve Strough, 2010), çocukların da farklı kültürlerde olsalar bile kendi gruplarında yer alan cinsiyetlere yönelik davranışları sezinlemesine yol açmıştır (Leaper, 1994). Daha farklı bir anlatımla, toplumsal cinsiyetçi ayrım ya da aynı cinsiyete yakınlık, basmakalıp toplumsal cinsiyetçi davranışların gelişmesine katkı sağladığı için (Martin ve ark., 2012), yaratıcı yazma sırasında, çocuklar, kendi cinsiyetindeki karakterlere karşı olumlu bir tutum sergilerken diğer cinsiyetlere yönelik olumsuz tavır takınabilir. Bununla birlikte, kız çocukları, oluşturdukları karakterleri kadına yönelik toplumsal cinsiyetçi rollerle betimlerken; erkek çocukları, oluşturdukları karakterleri erkeğe yönelik toplumsal cinsiyetçi rollerle betimleyebilir.

Yaratıcı yazma, sıradan alışkanlıkların, tabuların ya da toplumsal ve kültürel engellerin dışına adım atılmasına, sorgulanmasına, olaylara farklı açılardan bakılmasına ve eleştirel düşüncenin gelişmesine katkı sağlar. Bu yönüyle, yaratıcı yazma, özgürce yazabilmek (Susar Kırmızı ve Beydemir, 2012), daha önce bilinmeyen imgelerin, düşüncelerin ya da duyguların farklılaştırılması (Kinzie, 1999) ve bireyin kendinin farkında olmasıdır (Sampson, 2004). Bu yönüyle, yaratıcı düşünen, sorgulayan, eleştiren, çözüm üreten, farklı bakış açısına sahip bireylerin ortaya çıkmasında yazma becerisinin katkısı yadsınamaz. Bu bağlamda, farklııkların farkında olunması, alışımışın dışına çıkılması, kalıp yargılarla düşünülmemesi, bireyin basmakalıp ele alınmaması, insanın kendi içinde olan yaratıcı gizil gücü bulgulaması, kendini keşfetmesi, kendi olanaklarını ve sınırlarını tanıması yaratıcı yazmanın insana sunduğu olanakları ortaya koymaktadır (İpşiroğlu, 2006). Bütün bu yönleriyle, yaratıcı yazma sürecinde, çocuk ya da yetişkinler, kadın ve erkeğe yönelik olarak geleneksel bakış açısının farkında oldukları için cinsiyetleri kalıp bir biçimde sunan kurgular oluşturmayabilirler ve karakterlere basmakalıp roller yüklemeyebilirler.

$\mathrm{Bu}$ araştırmanın amacı, yaratıcı yazma çalışmasıyla öğrencilerin toplumsal cinsiyet algılarını ortaya çıkarmaktır. Bu durum, hem öğrencilerin yazılarının toplumsal cinsiyet ile olan ilişkisini ortaya çıkartacaktır hem de Türk kültüründe öğrencilerin yazdıkları yazılardaki toplumsal cinsiyetçi durumların başka kültürlerle benzer özellikler taşıyıp taşımadığı karşılaştırılacaktır. Bununla birlikte, toplumda kadın ve erkeğin nitelikleri ve rolleri ile ilgili tutum ve davranışların çocuklar tarafından yazılan öykülerde açık bir biçimde görülmesi (Trepanier ve Romatowski, 1985), toplumsal cinsiyet ile ilgili ortaya çıkabilecek durumların yaratıcı yazma çalışmasıyla yapılmasını gerekli kılmıştır. Çünkü 
yaratıcı yazma, var olan durumları, olayları ve kişileri daha alışılmışsın dışında ele alınmasını sağlamaktadır (Stuart, 2005). Aynı zamanda, yaratıcı yazma, öğrencilerin bireysel izlenimi için önemli bir araçtır ve bu araç toplumsal cinsiyet ile ilgili algıların araştırılmasında zengin bir kaynaktır (Graham ve Perin, 2007). Böylelikle, farklı yaş ve cinsiyette bulunan öğrencilerin toplumsal cinsiyet ile ilgili tutum, davranış ve algılarındaki durumlar da ortaya çıkarılabilir.

\section{Yöntem}

\section{Araştırma Deseni}

Bu araştırma, üniversite, ortaöğretim ve ilköğretim öğrencileri ile yetişkinlerin yazdıkları masallarda ortaya koydukları prens, prenses, cadı ve ejderhaya yönelik toplumsal cinsiyet rollerin incelendiği nitel bir araştırmadır. Nitel araştırma, gözlem, görüşme ve doküman analizi gibi nitel veri toplama yöntemlerinin kullanıldığı, algıların ve olayların doğal ortamda, gerçekçi ve bütüncül bir biçimde ortaya konmasına yönelik nitel bir sürecin izlendiği araştırma olarak tanımlanır. Başka bir deyişle, nitel araştırma, kuram oluşturmayı temel alan bir anlayışla sosyal olguları bağlı bulundukları çevre içerisinde araştırmayı ve anlamayı ön plana alan bir yaklaşımdır (Yıldırım ve Şimşek, 2011).

\section{Araştırma Grubu}

Araştırmanın katılımcılarını Amasya ilinde üniversite, ortaöğretim ve ilköğretim süreçlerinde eğitimlerini sürdürmekte olan 57 öğrenci ile 5 yetişkin oluşturmaktadır ( 27 kız, 35 erkek). Veri toplama sürecinde araştırmacı tarafından farklı düzeylerde yer alan 542 kişiye ulaşılıp araştırma konusuna uygun bir biçimde yaratıcı yazma çalışmaları yapılmasına karşın Creswell (2016)'in araştırmayı karakterize eden küçük sayılı örneklemlerin araştırma sürecini daha iyi yansıtacağı düşüncesinden yola çıkılarak araştırmaya katılan kişi sayısının azaltılmasına karar verilmiştir. Bu çalışmada, araştırma sürecine yetişkinlerin de alınmasının nedeni ise öğrencilerle karşılaştırma yapabilmektir. Bu yönüyle, katılımcılar, araştırmaya uygun örnekleme yoluyla seçilmiştir. Katılımcıların yaş aralığı 7 ile 37 arasında değişmekte olup ortalama yaşları 17.83 (S.S: 51.48)'dür. Araştırma, ilköğretim sürecinin üçüncü, beşinci, altıncı ve sekizinci sınıf düzeylerini yansıtan ve her düzeyden 5 öğrenci olmak üzere toplam 20 (\% 32) öğrenci ile ortaöğretim sürecinin dokuzuncu, onuncu, on birinci, on ikinci sınıf düzeylerini yansıtan ve her düzeyden 5 öğrenci olmak üzere toplam 20 (\% 32) öğrenci ile yürütülmüştür. İlköğretim ve ortaöğretimin farklı düzeylerinden aynı sayıda öğrenci seçilmesinin nedeni ise, farklı sınıf düzeylerinin araştırmada eşit oranda sunulmak istenmesidir. Üniversite öğrencilerinin tamamı 10 (\%16), farklı bölümlere devam etmekte olan farklı sınıf düzeylerinde bulunan öğrencilerdir. Pedagojik formasyon öğrencilerinin tamamı ise, 7 (\%12) birinci sınıf öğrencileridir. Bununla birlikte, üniversite eğitimlerini tamamlamış 5 (\%8) yetişkin de öğrencilerle karşılaştırma yapabilmek için araştırma sürecine alınmıştır. Araştırmanın farklı yaş ve 
düzeylerdeki katılımcılarla yürütülmesinin nedeni ise, her yaş ve düzeyde yaratıcı yazma ile ortaya çıkabilecek toplumsal cinsiyet algılarını ortaya çıkartıp karşılaştırma yapabilmektir.

\section{Verilerin Toplanması ve Çözümlenmesi}

Bu araştırmada, öğrencilere kişisel bilgi formu ve tek sorudan oluşan bir anket uygulanmıştır. Kişisel bilgi formunda öğrencilerin cinsiyeti, yaşı, sınıf düzeyi ve bölümlerini belirtmeleri istenmiştir. Tek sorudan oluşan anket sorusunda ise öğrencilerden içerisinde prens, prenses, cadı ve ejderhanın olduğu bir masal yazmaları istenmiştir. Daha sonra, katılımcıların bu masallarda prens, prenses, cadı ve ejderhayı nasıl betimlendikleri incelenmiştir. Başka bir ifadeyle, öğrencilerin prens, prenses, cadı ve ejderhayı nasıl betimlendiğine ilişkin yazdıkları masallara içerik analizi uygulanmıştır. İçerik analizinde ortaya çıkan izlekler (tema) sınıflandırılmış ve daha sonra bu sınıflandırmalar frekans ve yüzdeler aracılı̆ı̆yla rapor edilmiştir. Bununla birlikte, bazı katılımcılar prens, prenses, cadı ve ejderhayı betimlerken nötr ifadeler kullanmıştır. Örneğin, bir katılımcı prensesi betimlerken "Prensesi alıp gitmiş" ifadesini kullanmıştır. Bu ifadede prenses nötr bir şekilde betimlenmiştir. Bu yönüyle, nötr ifadeler, araştırma sürecine dahil edilmemiştir. Verileri elde etme sürecinde, bazı katılımcılar ise prens, prenses, cadı ve ejderhayı betimlerken birden fazla betimleme kullanmıştır. Örneğin, bir katılımcı "Prensesi kötü bir cadı kaçırdı." ifadesinde, prensesi güçsüz olarak; cadıyı ise kötü olarak betimlemiştir. Böyle durumlarda, her iki izleğe yönelik olarak yapılan betimlemeler ayrı ayrı sınıflandırılmıştır. Bu sınıflandırmalar ise, hem Macionis (2015)'in ortaya koyduğu toplumsal cinsiyet rollere yönelik izlekler hem de inceleme sürecinde kodlamaların ifade ettiği betimlemeler sonucunda araştırmacılar tarafından üretilen izlekler göz önünde bulundurularak gerçekleştirilmiştir. Tablo 1'de, öğrencilerin yazdıkları masallarda prens, prenses, cadı ve ejderhanın kodlamalarına ilişkin örnek ifadeler verilmiştir. Bu kodlamalara yönelik verilen örnek ifadeler "Ki: Katılımcı Illköğretim, KO: Katıımcı Ortaöğretim, KÜ: Katılımcı Üniversite, KF: Katılımcı Formasyon, KY: Katılımcı Yetişkin" biçiminde kısaltmalarla verilmiştir.

Tablo 1. Prens, Prenses, Cadı ve Ejderhanın Kodlamalarına ilişkin Örnek Ifadeler

\begin{tabular}{ll}
\multicolumn{1}{c}{ İzlekler } & \multicolumn{1}{c}{ Örnek ifade (Kodlamalar) } \\
\hline $\begin{array}{l}\text { Prens } \\
\text { Başarılı }\end{array}$ & $\begin{array}{l}\text { Prens, kuleye çıkmış ve prensi kurtarmış. } \\
\text { Hırslı }\end{array}$ \\
Akıllı & $\begin{array}{l}\text { Ben bu prensesi kurtarmadan hiçbir yere gitmem der. } \\
\text { oluştuğunu anlamış. }\end{array}$ \\
Güçlü & Prens, buna dayanamayıp ejderhayla savaşıp onu öldürmüş. \\
\hline Prenses & Bir gün prensesi prens kaçırdı. \\
Güçsüz & Prensesi kurtardılar. \\
Edilgen & En sonunda prens prensesi öptü ve prenses birden ayıldı. \\
Cinsel Nesne &
\end{tabular}




\begin{tabular}{ll}
$\begin{array}{l}\text { Bağımlı } \\
\text { Duygusal }\end{array}$ & $\begin{array}{l}\text { Bir gün prenses babasından izin alarak uzaklara gitmek için izin istemiş. } \\
\text { Prenses kaldırımın üstünde ağlıyordu. }\end{array}$ \\
\hline $\begin{array}{l}\text { Cadı } \\
\text { Kötü }\end{array}$ & $\begin{array}{l}\text { Cadı, onları kıskanmış ve kızlarına büyü yapmış. } \\
\text { Çirkin }\end{array}$ \\
Kıskanç & $\begin{array}{l}\text { Prens şatoya doğru giderken önüne çirkin bir prens çıkmış. } \\
\text { Çok güzelmiş prenses cadı da onu çok kıskanıyormuş. }\end{array}$ \\
\hline Ejderha & Bu prensesi ejderha hapsetmiş \\
Kötü & Cadı, ejderhayı kötülükler için hep yanında gezdirirmiş \\
Edilgen & Bunu gören ejderha çok kıskanmış \\
Kıskanç & Ejderha buna sinirlenerek ağzından ve burnundan ateş çıkartır. \\
Korkutucu &
\end{tabular}

Bu araştırmada, bu örnek ifadeler doğrultusunda ortaya konulan prens, prenses, cadı ve ejderhaya yönelik tümce düzeyinde ele alınan kodlamalar, araştırmacı dışında nitel araştırma konusunda deneyimli başka bir araştırmacı tarafından yeniden değerlendirilmiştir. Bu yönüyle, her iki araştırmacının yapmış oldukları değerlendirmelerindeki benzerlik ve farklılıklar karşılaştırılarak ortaya çıkan kodlamalar araştırmacılar tarafından yeniden sınıflandırılmıştır. Bu yaklaşım, verilen elde edilme sürecinde bireysel varsayımları, önyargıları, yönelimleri ve öznelliği azaltmak ve araştırmanın güvenirliliğini arttırmak amacıyla kullanılmıştır (Creswell, 2016). Daha sonra her iki araştırmacı, kodlamaları sınıflandırdıktan sonra frekans ve yüzdelerde ortaya çıkabilecek yanlışlıkları gidermek için frekans ve yüzdeler ayrı ayrı hesaplanmıştır. Son olarak, her iki araştırmacının yapmış oldukları hesaplamalar incelendikten sonra rapor edilmiştir.

\section{Bulgular}

Bu araştırmada, öğrenci ve yetişkinlerin yazdıkları masallarda betimledikleri prens, prenses, cadı ve ejderhaya yönelik kodlamalara yönelik frekans ve yüzdeler aşağıda belirtilmiştir.

Tablo 2. Prensesle Ilgili Kodlamalara Yönelik Frekans ve Yüzdeler

\begin{tabular}{|c|c|c|c|c|c|c|c|c|c|c|}
\hline \multirow{2}{*}{ İzlekler } & \multicolumn{2}{|c|}{ İlköğretim } & \multicolumn{2}{|c|}{ Ortaöğretim } & \multicolumn{2}{|c|}{ Üniversite } & \multicolumn{2}{|c|}{ Formasyon } & \multicolumn{2}{|c|}{ Yetişkin } \\
\hline & $f$ & $\%$ & $f$ & $\%$ & $f$ & $\%$ & $f$ & $\%$ & $f$ & $\%$ \\
\hline \multicolumn{11}{|l|}{ Prenses } \\
\hline Güçsüz & 55 & 15.9 & 60 & 13.5 & 46 & 11.5 & 34 & 13.2 & 24 & 15.1 \\
\hline Cinsel Nesne & 32 & 9.2 & 51 & 11.5 & 49 & 12.2 & 28 & 10.9 & 21 & 13.2 \\
\hline Bağımlı & 46 & 13.3 & 66 & 14.9 & 50 & 12.5 & 40 & 15.6 & 20 & 12.6 \\
\hline Duygusal & 51 & 14.7 & 54 & 12.2 & 45 & 11.2 & 35 & 13.6 & 21 & 13.2 \\
\hline Sezgisel & 8 & 2.3 & 9 & 2.03 & 5 & 1.2 & 2 & 0.8 & 0 & 0 \\
\hline Utangaç & 21 & 6.1 & 30 & 6.8 & 43 & 10.8 & 24 & 9.3 & 12 & 7.6 \\
\hline Edilgen & 49 & 14.2 & 67 & 15.1 & 65 & 16.2 & 45 & 17.5 & 25 & 15.8 \\
\hline Hassas & 24 & 6.9 & 32 & 7.2 & 40 & 9.9 & 21 & 8.17 & 10 & 6.3 \\
\hline $\begin{array}{l}\text { Görünüm olarak } \\
\text { çekici (Güzel) }\end{array}$ & 60 & 17.3 & 65 & 14.7 & 47 & 11.7 & 25 & 9.72 & 26 & 16.4 \\
\hline Çirkin & 0 & 0 & 2 & 0.5 & 0 & 0 & 0 & 0 & 0 & 0 \\
\hline Cesur & 1 & 0.3 & 3 & 0.7 & 5 & 1.2 & 2 & 0.8 & 0 & 0 \\
\hline Akıllı & 3 & 0.9 & 4 & 0.9 & 6 & 1.5 & 1 & 0.4 & 0 & 0 \\
\hline
\end{tabular}


Tablo 2'de, ilköğretim sürecinde öğrenciler tarafından oluşturulan masallarda prenses ile ilgili betimlemeler daha çok 60 (\% 17.3) "güzel", 55 (\% 15.9) "güçsüz", 51 (\% 14.7) "duygusal", 49 (\% 14.2) "edilgen", 46 (\% 13.3) "bağımlı" olarak yansıtılırken ortaöğretim sürecinde daha çok 67 (\% 15.1) "edilgen", 66 (\% 14.9) "bağımlı", 65 (\% 14.7) "görünüm olarak çekici", 60 (\% 13.5) "güçsüz", 54 (\% 12.2) "duygusal", 51 (\% 11.5) "cinsel nesne" olarak yansıtılmıştır. Üniversite düzeyinde öğrenciler tarafından oluşturulan masallarda prenses ile ilgili betimlemeler daha çok 65 (\% 16.2) "edilgen", 50 (\% 12.5) "bağımlı", 49 (\% 12.2) "cinsel nesne", 47 (\% 11.7) " görünüm olarak çekici", 46 (\% 11.5) "güçsüz", 45 (\% 11.2) "duygusal" olarak yansıtılırken formasyon sürecinde daha çok 45 (\% 17.5) "edilgen", 40 (\% 15.6) "bağımlı", 35 (\% 13.6) "duygusal", 34 (\% 13.2) "güçsüz", 28 (\% 10.9) "cinsel nesne" olarak yansıtılmıştır. Bununla birlikte, yetişkinlerin yazmış oldukları masallarda prenses ile ilgili betimlemelerin daha çok 26 (\% 16.4) "görünüm olarak çekici", 25 (\% 15.8) "edilgen", 24 (\% 15.1) "güçsüz", 21 (\% 13.2) "cinsel nesne", 21 (\% 13.2) "duygusal", 20 (\% 12.6) "bağımlı" olduğu görülmüştür. Bütün düzeylerde "çirkin", "cesur" ve "akıllı" izleklere yönelik betimlemelerin oldukça az olduğu görülmektedir. Özellikle yetişkin düzeyinde "çirkin", "cesur" ve "akıllı" izleklerine yönelik betimlemelerin hiç olmaması ise dikkat çekicidir. Öğrenci ve yetişkinlerin yazılarında yer alan prenses karakterinin "görünüm olarak çekici", "güçsüz", "duygusal", "bağımlı" ve "cinsel nesne" olarak yansıtılmasına yönelik örnekler aşağıda verilmiştir:

Prenses karakterinin görünüm olarak çekici (güzel) olarak yansıtılmasına yönelik örnekler

- Güzeller güzeli bir prensesleri olmuş (Ki).

- Prenses çok güzelmiş (KO).

- Bir zamanlar güzel mi güzel, iyi mi iyi bir prenses varmış (KÜ).

- Bir gün prens gezmeye çıkar ve evinin bahçesinde çiçek toplayan çok güzel bir prenses görür $(\mathrm{KF})$.

- Tam o sırada çok güzel bir prenses içeri girmiş (KY).

Prenses karakterinin güçsüz olarak yansıtılmasına yönelik örnekler

- Cadı çok büyük bir büyü yapmış. Prenses hastalanmış ve yataklara düşmüş (Ki).

- $O$ cadı prensesi öldürmüş (KO).

- Prenses başta korkmuş. Kaçmaya çalışmış (KÜ).

- Bu ejderha kasabayı alev içinde bırakıp prensesi almış. Cadı da bunu fırsat bilerek prensesi kurbağaya çevirmiş (KF).

- Prenses baygın haldeymiş ve güzel kız yataklara düşmüş, hastalanmış (KY).

Prenses karakterinin duygusal olarak yansıtılmasına yönelik örnekler

- Prenseste kaldırımın üstünde ağlıyordu (Ki).

- Prenses üzülmüş ama prens onun üzülmesini istemeyince ona sarılmış, sakinleştirmiş (KO). 
- Prenses evden kaçtığına çok üzülmüş (KÜ).

- Bu arada prenses çok şaşırmış ve hıçkıra hıçkıra ağlayarak evine gitmiş (KF).

- Prenses bu duruma çok üzülmüş (KY).

Prenses karakterinin bağımlı olarak yansıtılmasına yönelik örnekler

- Prensin babası da bu yüzden kızı oğluna alır (Ki).

- (Prens) prensesi camdan kaçırıp babasına götürür, (prenses) babasının izniyle evlenir (KO).

- Tamam, prensesi istemeye gidelim (KÜ).

- Ama o da benimle evlendikten sonra prenses olacak (KF).

- Bir gün prenses babasından izin alarak uzaklara gezmek için gitmek istemiş (KY).

Prenses karakterinin cinsel nesne olarak yansıtılmasına yönelik örnekler

- En sonunda prens öpmüş ve prenses ayılmış (Ki).

- Prensesi şatosuna götürmüş ve günlerce uyanamayınca onu öpmüş ve prenses uyanmış (KO).

- Prenses bu durumdan o kadar çok hoşlanmaya başlamış ki bayılmış ve prens onu kucağına alarak prensesi odasına taşımış (KÜ).

- Prens prensesin dudaklarından öptü (KF).

- Prens daha fazla dayanamayarak prensese sarılıp dudaklarından öpmüş (KY).

Tablo 3. Prens Ile Ilgili Kodlamalara Yönelik Frekans ve Yüzdeler

\begin{tabular}{|c|c|c|c|c|c|c|c|c|c|c|}
\hline \multirow{2}{*}{ İzlekler } & \multicolumn{2}{|c|}{ İlköğretim } & \multicolumn{2}{|c|}{ Ortaöğretim } & \multicolumn{2}{|c|}{ Üniversite } & \multicolumn{2}{|c|}{ Formasyon } & \multicolumn{2}{|c|}{ Yetişkin } \\
\hline & $f$ & $\%$ & $f$ & $\%$ & $f$ & $\%$ & $f$ & $\%$ & $f$ & $\%$ \\
\hline \multicolumn{11}{|l|}{ Prens } \\
\hline Baskın & 37 & 9.9 & 44 & 10.9 & 69 & 11.2 & 24 & 9.1 & 18 & 10.7 \\
\hline Başarılı & 41 & 11 & 38 & 9.5 & 64 & 10.4 & 25 & 9.5 & 17 & 10.1 \\
\hline Hırslı & 30 & 8 & 36 & 9 & 55 & 8.9 & 23 & 8.7 & 15 & 8.9 \\
\hline Akılcı & 31 & 8.3 & 24 & 6 & 39 & 6.3 & 19 & 7.2 & 13 & 7.7 \\
\hline Güçlü & 47 & 12.5 & 49 & 12.2 & 68 & 11 & 30 & 11.4 & 19 & 11.3 \\
\hline Güçsüz & 3 & 0.8 & 0 & 0 & 13 & 2.1 & 2 & 0.8 & 0 & 0 \\
\hline Cesur & 50 & 13.3 & 47 & 11.7 & 62 & 10 & 32 & 12.1 & 20 & 12 \\
\hline İddialı & 18 & 4.8 & 22 & 5.5 & 30 & 4.9 & 18 & 6.8 & 12 & 7.1 \\
\hline Cinsel Saldırgan & 7 & 1.9 & 25 & 6.2 & 47 & 7.6 & 22 & 8.3 & 14 & 8.3 \\
\hline Etkin & 45 & 12 & 44 & 10.9 & 60 & 9.7 & 33 & 12.5 & 21 & 12.5 \\
\hline Çözümleyici & 22 & 5.9 & 25 & 6.2 & 33 & 5.3 & 14 & 5.3 & 1 & 0.6 \\
\hline Edilgen & 5 & 1.3 & 3 & 0.7 & 6 & 1 & 0 & 0 & 0 & 0 \\
\hline İşbirlikçi & 1 & 0.3 & 5 & 1.2 & 5 & 0.8 & 0 & 0 & 1 & 0.6 \\
\hline $\begin{array}{l}\text { Görünüm olarak } \\
\text { çekici (Yakışıklı) }\end{array}$ & 38 & 10.1 & 40 & 10 & 64 & 10.4 & 22 & 8.3 & 17 & 10.1 \\
\hline
\end{tabular}

Tablo 3'te, ilköğretim sürecinde öğrenciler tarafından oluşturulan masallarda prens ile ilgili betimlemeler daha çok 50 (\% 13.3) "cesur", 47 (\% 12.5) "güçlü", 45 (\% 12) "etkin", 41 (\% 11) 
"başarılı", 38 (\%10.1) "görünüm olarak çekici" olarak yansıtılırken ortaöğretim sürecinde daha çok 49 (\% 12.2) "güçlü", 47 (\% 11.7) "cesur", 44 (\% 10.9) "baskın", 44 (\% 10.9) "etkin", 40 (\% 10) "görünüm olarak çekici ", 38 (\% 9.5) "başarıı" olarak yansıtılmıştır. Üniversite düzeyinde öğrenciler tarafından oluşturulan masallarda prens ile ilgili betimlemeler daha çok 69 (\% 11.2) "baskın", 68 (\% 11) "güçlü", 64 (\% 10.4) "görünüm olarak çekici", 64 (\% 10.4) "başarılı", 62 (\% 10) "cesur", 60 (\% 9.7) "etkin" olarak yansıtılırken formasyon sürecinde daha çok 33 (\% 12.5) "etkin", 32 (\% 12.1) "cesur", 30 (\% 11.4) "güçlü", 25 (\% 9.5) "başarılı", 24 (\% 9.1) "baskın" olarak yansıtılmışır. Bununla birlikte, yetişkinlerin yazmış oldukları masallarda prens ile ilgili betimlemelerin daha çok 21 (\% 12.5) "etkin", 20 (\% 12) "cesur", 19 (\% 11.3) "güçlü", 18 (\% 10.7) "baskın" olduğu görülmüştür. Öğrenci ve yetişkinlerin yazılarında yer alan prens karakterinin "görünüm olarak çekici", "cesur", "başarılı", "güçlü" ve "baskın" olarak yansıtılmasına yönelik örnekler aşağıda verilmiştir:

Prens karakterinin görünüm olarak çekici (yakışıkı) olarak yansıtılmasına yönelik örnekler

- Prenses kadar iyi kalpli bir prensmiş, oldukça da yakışıklıymış (Ki).

- Padişahın da bir tane oğlu varmış. O kadar yakışıklıymış ki bütün kızlar ona aşıkmış (KO).

- Her gece rüyasında uzak diyarlarda yaşayan yakışıklı mı yakışıkı bir prens görürmüş (KÜ).

- Zamanın birinde güzellikler ülkesinde yakışıklı mı yakışıklı bir prens varmış (KF).

- Bu prens çok yakışıklı, zengin bir prensmiş (KY).

Prens karakterinin cesur olarak yansıtılmasına yönelik örnekler

- Prens ejderhayı yakalayarak onu etkisiz hale getirmiş (Ki).

- Prens bu ejderhayı öldürerek halkını kurtarmak istiyormuş (KO).

- Prens prensesini de tutup ejderhanın üstüne atlamış (KÜ).

- Prens bunları duyunca prensesi o şatodan kurtarmak için ejderhayı öldürmeye karar vermiş ve çıkmış ejderhanın karşısına (KF).

- Prens vurduğu her kılıç darbesinde ejderhayı yaralamış. Ejderha artık çok zayıflamış ve kaçmış (KY).

Prens karakterinin başarılı olarak yansıtılmasına yönelik örnekler

- Prens sayesinde prenses sonunda kuleden kurtulmayı başarmış (Ki).

- Prens zorlu bir yolculuk sonucu ejderhaya ulaşmış (KO).

- Kara şövalye bizim prensin kazandığı başarıları hiç çekemezmiş KÜ).

- Prens ejderhayı da cadıyı da öldürerek ve prensesi de alarak saraya dönmüş (KF).

- Prens önüne çıkan türlü türlü engelleri aşıyormuş (KY).

Prens karakterinin güçlü olarak yansıtılmasına yönelik örnekler

- Prens de büyüdükçe daha da güçlenmiş (Ki). 
- Prens ejderhayı da cadıyı da öldürerek ve prensesi de alarak saraya dönmüş (KO).

- (Prens) Eğer ejderhayı yok etmezse onu öldürmekte tehdit etmiş. Yaşlı cadı ise bu prensten korkmuş (KÜ).

- Prens vurduğu her kılıç darbesinde ejderhayı yaralamış. Ejderha artık çok zayıflamış ve kaçmış (KF).

- Cadının bütün sihirlerine ters tepki veren Nebillo (prens) cadıyı da güçsüz bırakmış (KY).

\section{Prens karakterinin baskın olarak yansıtılmasına yönelik örnekler}

- Prens kıza prensesim olur musunuz demiş ve kız kabul etmiş (Ki).

- Olup bitenleri öğrenen prens kızın yanına gelerek artık sen benim prensesimsin diyerek ona sarılmış (KO).

- Prenses her şeyden vazgeçebilirmiş prens için (KÜ).

- Prens ejderhayı da cadıyı da öldürerek ve prensesi de alarak saraya dönmüş (KF).

- Prens, ben bu prensesi kurtarmadan hiçbir yere gitmem, der (KY).

Tablo 4. Cadı ve Ejderha Ile Ilgili Kodlamalara Yönelik Frekans ve Yüzdeler

\begin{tabular}{|c|c|c|c|c|c|c|c|c|c|c|}
\hline \multirow{2}{*}{ İzlekler } & \multicolumn{2}{|c|}{ İlköğretim } & \multicolumn{2}{|c|}{ Ortaöğretim } & \multicolumn{2}{|c|}{ Üniversite } & \multicolumn{2}{|c|}{ Formasyon } & \multicolumn{2}{|c|}{ Yetişkin } \\
\hline & $f$ & $\%$ & $f$ & $\%$ & $f$ & $\%$ & $f$ & $\%$ & $f$ & $\%$ \\
\hline \multicolumn{11}{|l|}{ Cadı } \\
\hline Kötü & 42 & 25.6 & 46 & 26 & 35 & 25.9 & 25 & 24.5 & 17 & 23.9 \\
\hline Kıskanç & 39 & 23.7 & 41 & 23.2 & 32 & 23.7 & 23 & 22.5 & 18 & 25.4 \\
\hline Korkutucu & 45 & 27.4 & 50 & 28.2 & 37 & 27.4 & 30 & 29.4 & 20 & 28.1 \\
\hline Çirkin & 38 & 23.2 & 38 & 21.5 & 27 & 20 & 24 & 23.5 & 16 & 22.6 \\
\hline İyi & 0 & 0 & 2 & 1.1 & 4 & 3 & 0 & 0 & 0 & 0 \\
\hline \multicolumn{11}{|l|}{ Ejderha } \\
\hline Kötü & 34 & 30.1 & 32 & 27.6 & 34 & 29.6 & 22 & 25.8 & 17 & 34 \\
\hline Edilgen & 30 & 26.5 & 27 & 23.3 & 25 & 21.7 & 19 & 22.4 & 14 & 28 \\
\hline Kıskanç & 8 & 7.07 & 13 & 11.2 & 17 & 14.8 & 18 & 21.2 & 12 & 24 \\
\hline Korkutucu & 40 & 35.4 & 42 & 36.2 & 35 & 30.4 & 25 & 29.4 & 17 & 34 \\
\hline İyi & 1 & 0.9 & 2 & 1.7 & 4 & 3.5 & 1 & 1.2 & 0 & 0 \\
\hline
\end{tabular}

Tablo 4'te, ilköğretim sürecinde öğrenciler tarafından oluşturulan masallarda cadı ile ilgili betimlemeler daha çok 45 (\% 27.4) "korkutucu", 42 (\% 25.6) "kötü", 39 (\% 23.7) "kıskanç", 38 (\% 23.2) "çirkin" olarak yansıtııırken ejderha ile ilgili betimlemeler daha çok 40 (\% 35.4) "korkutucu", 34 (\% 30.1) "kötü", 30 (\% 26.5) "edilgen" olarak yansıtılmıştır. Ortaöğretim sürecinde ise cadı ile ilgili betimlemeler daha çok 50 (\% 28.2) "korkutucu", 46 (\% 26) "kötü", 41 (\% 23.2) "kıskanç", 38 (\% 21.5) "çirkin" olarak yansıtılırken ejderha ile ilgili betimlemeler daha çok 42 (\% 36.2) "korkutucu", 32 (\% 27.6) "kötü", 27 (\% 23.3) "edilgen" olarak yansıtılmıştır. Üniversite düzeyinde öğrenciler tarafından oluşturulan masallarda cadı ile ilgili betimlemeler daha çok 37 (\% 27.4) "korkutucu", 35 (\% 25.9) "kötü", 32 (\% 23.7) "kıskanç", 27 (\% 20) "çirkin" olarak yansıtılırken ejderha ile ilgili betimlemeler daha çok 35 (\% 30.4) "korkutucu", 34 (\% 29.6) "kötü", 25 (\% 21.7) "edilgen" olarak yansıtılmıştır. 
Formasyon düzeyinde öğrenciler tarafından oluşturulan masallarda cadı ile ilgili betimlemeler daha çok 30 (\% 29.4) "korkutucu", 25 (\% 24.5) "kötü", 24 (\% 23.5) "çirkin", 23 (\% 22.5) "kıskanç" olarak yansıtılırken ejderha ile ilgili betimlemeler daha çok 25 (\% 29.4) "korkutucu", 22 (\% 25.8) "kötü", 19 (\% 22.4) "edilgen" olarak yansıtılmıştır. Bununla birlikte, yetişkinlerin yazmış oldukları masallarda cadı ile ilgili betimlemelerin daha çok 20 (\% 28.1) "korkutucu", 18 (\% 25.4) "kıskanç", 17 (\% 23.9) "kötü" olduğu görülürken ejderha ile ilgili betimlemelerin 17 (\% 34) "korkutucu", 17 (\% 34) "kötü", 14 (\% 28) "edilgen" olduğu görülmüştür. Bütün düzeylerde "iyi" izleğine yönelik betimlemelerin oldukça az olduğu görülmektedir. Öğrenci ve yetişkinlerin yazılarında yer alan cadı ve ejderha karakterinin "kötü", "korkutucu" ve "kıskanç" olarak yansıtılmasına yönelik örnekler aşağıda verilmiştir:

Cadı ve ejderha karakterinin kötü olarak yansıtılmasına yönelik örnekler

- Kötü kalpli cadının kendi gibi kötü ejderhası varmış (Ki).

- Cadının emriyle ejderha ağzındaki ateşle prensi yakmış (KO).

- Ormanda zebaniden de çirkin bir tane cadı varmış. Bu cadı bunların mutluluklarını bozmak için kulübeye gelmiş (KÜ).

- Karşılarına aniden kötülükleriyle nam salmış Cadı Şira çıkmış. Cadı onları zorla mağarasına götürmüş (KF).

- Onun kötü kalpli bir cadı olduğunu bilmiyormuş. Cadı onu kulübeye kapatmış (KY).

Cadı ve ejderha karakterinin korkutucu olarak yansıtılmasına yönelik örnekler

- Ejderha cadıya hizmet eden bir canavarmış (Ki).

- Cadının siyah upuzun saçları, siyah kıyafetleri uzun burnu ile korkutucu bir izlenimi varmış (KO).

- Bu ejderha o kadar büyük ve korkutucu görünüyormuş ki insanlar onun gölgesinden bile korkarmış (KÜ).

- Prensesi korumak için görevlendirilen şatonun kapısında bekleyen kocaman dişleri ve kıpkırmızı gözü olan bir ejderha varmış (KF).

- Mağaranın girişinde önce cadıyı sonra büyük bir ejderha gören askerler korkudan kaçıp saklanmışlar (KY).

Cadı ve ejderha karakterinin kıskanç olarak yansıtılmasına yönelik örnekler

- Bunu gören ejderha ve cadı çok kıskanmış (Ki).

- Cadı prensesin güzelliğini çok kıskanmış (KO).

- Ormanın derinliklerinde alaca bir geyiğin peşinden giderken bir de bakmış ki kocaman bir ejderhanın üstünde çirkin ve bir o kadar da korkunç bir cadı varmış. Cadı çirkinliğinin farkında olduğu için diyarın en güzel kızını bulup onu yakalayarak büyüyle onun güzelliğine sahip olmak istiyormuş (KÜ). 
- Cadının tek amacı prensesi mutsuz görmekmiş çünkü onun güzelliğini kıskanırmış (KF).

- Kızın güzelliğini kıskananlar da olurmuş o zamanlar. Onların biri de çok uzaklarda yaşayan, ormanların hayvanlarına hep zarar veren bir cadı yaşamıştır (KY).

\section{Tartışma}

Bu araştırmada, farklı yaş ve cinsiyette bulunan öğrencilerin yazdıkları yaratıcı yazılardaki toplumsal cinsiyet algılarının birbirine benzer olduğu ortaya çıkartılmıştır. Daha açık bir anlatımla, bu araştırmada, ilköğretim, ortaöğretim, üniversite öğrencileri ile yetişkinlerin yaratıcı yazma sürecinde prens, prenses, cadı ve ejderha karakterlerini basmakalıp toplumsal cinsiyet rollerle betimlediği belirlenmiştir. Bu durum, Ben (1981) tarafından ortaya konan toplumsal cinsiyet şema kuramıyla da örtüşmektedir. Çünkü bu kurama göre, çocuklar, kendi yaşadıkları toplum ve kültürde kadın ve erkek olmanın ne anlama geldiğini, hangi rollere girmeleri gerektiğini, hangi davranışları sergilemeleri gerektiğini, duygu ve düşüncelerini nasıl yansıtmaları gerektiğini öğrenirler. Bu yönüyle, çocuklar da toplumun bir parçası olduğuna göre duygu, düşünce ve davranışlarını toplum ve kültürün beklentilerine ve cinsiyet kurallarına uygun olacak bir biçimde düzenlerler. Araştırmada, prenses karakterinin her düzeyde daha çok güzel, güçsüz, duygusal, edilgen, bağımlı ve cinsel nesne olarak; prens karakterinin ise, daha çok yakışıklı, güçlü, başarılı, cesur, baskın ve etkin olarak betimlenmesi, hem yazma sürecinde toplumsal cinsiyet algının farklı yaş ve cinsiyette ortaya çıktığını hem de yaş ve cinsiyet değişse de kadın ve erkeğe yönelik basmakalıp toplumsal cinsiyetçi algının sürdürüldüğünü ortaya koymaktadır. Bununla birlikte, prens ve prenses karakterlerinde ortaya çıkan bu durum, kendini cadı ve ejderha karakterlerinde de göstermektedir. Çünkü her iki karakter farklı yaş ve gelişim düzeyinde sürekli olarak kötü, korkutucu, kıskanç, edilgen ve çirkin olarak betimlenmiştir. Oysa yaratıcı yazma sürecinde, araştırmacı tarafından verilen karakterlere yönelik herhangi bir betimleme yapılmamış olmasına karşın bütün düzeylerde cadı ve ejderha karakterlerinin daha çok kötü, korkutucu, kıskanç, edilgen ve çirkin olması, toplumun ve kültürün ortak bilinçaltında yatan toplumsal cinsiyet özelliklerinin kalıp yargılar biçiminde öğrenildiğini ve yaşatıldığını ortaya koymaktadır (Ben, 1981). Çünkü kalıp yargılar öğrenilip paylaşılır, güçlü ve dayanıklıdır ve toplumsal anlamda genel kanıları meşru kılarak nitelemeleri abartır ya da aşırı basitleştirir (Turner-Bowker, 1996). Bütün bu durumlar, toplumun ve kültürün değerleri tarafından yapılandırılan, biçimlendirilen ve korunan toplumsal cinsiyetin (Tepper ve Cassidy, 1999) yaratıcı yazma sürecinde bile çocuk ve yetişkinlerin her iki cinsiyete yönelik olarak tutum ve davranışlarında ortaya çıktığını göstermektedir.

Bu araştırmada, yaratıcı yazma sürecine katılan ilköğretim düzeyindeki öğrencilerin yazıları incelendiğinde, prenses karakterinin daha çok 60 (\% 17.3) "güzel", 55 (\% 15.9) "güçsüz", 51 (\% 14.7) "duygusal", 49 (\% 14.2) "edilgen", 46 (\% 13.3) "bağımlı" olarak yansıtılırken daha az bir biçimde 0 (\% 0) "çirkin", 1 (\% 0.3) "cesur" ve 3 (\% 0.9) "akıllı" olarak yansıtılması; prens karakterinin daha çok 50 (\% 
13.3) "cesur", 47 (\% 12.5) "güçlü", 45 (\% 12) "etkin", 41 (\% 11) "başarılı", 38 (\%10.1) "görünüm olarak çekici" olarak yansıtılırken daha az bir biçimde 5 (\% 1.3)" edilgen", 3 (\% 0.8) "güçsüz" ve 1 (\% 0.3) "işbirlikçi" olarak yansıtılması, kadın ve erkek cinsiyetine yönelik bakış açısının erken dönemde basmakalıp bir biçimde sezinlenmiş olduğunu ortaya koymaktadır. Bununla birlikte, ortaöğretim düzeyindeki öğrencilerin yazıları incelendiğinde ise, prenses karakterinin daha çok 67 (\% 15.1) "edilgen", 66 (\% 14.9) "bağımlı", 65 (\% 14.7) "güzel", 60 (\% 13.5) "güçsüz", 54 (\% 12.2) "duygusal", 51 (\% 11.5) "cinsel nesne" olarak yansıtılırken daha az bir biçimde 4 (\% 0.9) "akıllı", 3 (\% 0.7) "cesur" ve 2 (\% 0.5) "çirkin" olarak yansıtılması; prens karakterinin daha çok 49 (\% 12.2) "güçlü", 47 (\% 11.7) "cesur", 44 (\% 10.9) "baskın", 44 (\% 10.9) "etkin", 40 (\% 10) "görünüm olarak çekici", 38 (\% 9.5) "başarıı" olarak yansıtıııken daha az bir biçimde 5 (\% 1.2) "işbirlikçi", 3 (\% 0.7) "edilgen" ve 0 (\% 0) "güçsüz" olarak yansıtılması, ilköğretim sürecindeki kadın ve erkek cinsiyetine yönelik geleneksel bakış açısının ortaöğretim sürecinde de sürdürüldüğünü ortaya koymaktadır. Bu araştırmada, 7 ile 18 yaş arasındaki ilköğretim ve ortaöğretim sürecinde bulunan çocukların yazılarında prens ve prensesle ilgili aynı rolleri ifade eden betimlemelerde bulunmaları, hem çocukluğun toplumsal cinsiyet kimliklerinin kazanıldığı önemli bir dönem olduğunu (McCabe, Fairchild, Grauerholz, Pescosolido ve Tope, 2011) hem de çocukların farklı cinsiyetlere yönelik olarak toplum tarafından yüklenen rolleri kanıksadığını ortaya koymaktadır (Bem, 1993).

Bu araştırmada, yaratıcı yazma sürecine katılan üniversite düzeyindeki öğrencilerin yazıları incelendiğinde, prenses karakterinin daha çok 65 (\% 16.2) "edilgen", 50 (\% 12.5) "bağımlı", 49 (\% 12.2) "cinsel nesne", 47 (\% 11.7) "güzel", 46 (\% 11.5) "güçsüz", 45 (\% 11.2) "duygusal" olarak yansıtııırken daha az bir biçimde 0 (\% 0) "çirkin", 5 (\% 1.2) "cesur" ve 6 (\% 1.5) "akıllı" olarak yansıtılması; prens karakterinin daha çok 69 (\% 11.2) "baskın", 68 (\% 11) "güçlü", 64 (\% 10.4) "görünüm olarak çekici", 64 (\% 10.4) "başarılı", 62 (\% 10) "cesur", 60 (\% 9.7) "etkin" olarak yansıtılırken daha az bir biçimde 5 (\% 1.3) "edilgen", 3 (\% 0.8) "güçsüz" ve 1 (\% 0.3) "işbirlikçi" olarak yansıtılması; kadın ve erkek cinsiyetlerinin belli toplumsal rollerle kalıplaştırıldığını ve basmakalıp bir biçimde öğrenildiğini ortaya koymaktadır. Bununla birlikte, formasyon düzeyindeki öğrencilerin yazıları incelendiğinde ise, prenses karakterinin daha çok daha çok 45 (\% 17.5) "edilgen", 40 (\% 15.6) "bağımlı", 35 (\% 13.6) "duygusal", 34 (\% 13.2) "güçsüz", 28 (\% 10.9) "cinsel nesne" olarak yansıtııırken daha az bir biçimde 0 (\% 0) "çirkin", 2 (\% 0.8) "cesur" ve 1 (\% 0.4) "akıllı" olarak yansıtılması; prens karakterinin daha çok 33 (\% 12.5) "etkin", 32 (\% 12.1) "cesur", 30 (\% 11.4) "güçlü", 25 (\% 9.5) "başarıı", 24 (\% 9.1) "baskın" olarak yansıtılırken daha az bir biçimde 0 (\% 0) "edilgen", 2 (\% 0.8) "güçsüz" ve 0 (\% 0) "işbirlikçi" olarak yansıtılması, eğitim bilimlerine yönelik ders alan bu düzeydeki öğretmen adaylarının kadın ve erkeğe yönelik toplumsal cinsiyet rollerini kanıksamış olduklarını ortaya koymaktadır. Bu araştırmada, 19 ile 25 yaş arasındaki üniversite ve formasyon sürecinde 
bulunan öğretmen adaylarının kadın ve erkeğe yönelik toplumsal cinsiyet anlayışlarının basmakalıp bir biçimde yerleşmiş olduğu görülmektedir. Daha açık bir anlatımla, formasyon öğrencilerinin yazılarında prenses rolüyle kadın karakterinin sürekli olarak güçsüz, edilgen, duygusal, bağımlı, çekici ve cinsel nesne olarak yansıtılması, kadını toplumsal yaşamda geleneksel bir biçimde ikincil bir konuma düşürürken prens rolüyle erkek karakterinin etkin, güçlü, baskın, başarılı ve cesur olarak yansıtılması, erkeği birincil konuma getirmiştir. Kadın ve erkeğin toplum içindeki konumlarının erkek cinsiyetini daha çok ön plana çıkarması ataerkil yapının güçlenmesine olanak tanıyabilir (Gooden ve Gooden, 2001). Bu anlayışın toplumda daha fazla yerleşmemesi için, kadın ve erkeği eşit bir biçimde gösterecek çağdaş yaklaşımların hem eğitim sistemi içerisinde canlı tutulması hem de sürekli eğitim anlayışının bir yansıması olarak demokratik yaşam kültürünün oluşturulması gerekir.

Bu araştırmada, yaratıcı yazma sürecine katılan yetişkin düzeyindeki katılımcıların yazıları incelendiğinde, prenses karakterinin daha çok 26 (\% 16.4) "güzel", 25 (\% 15.8) "edilgen", 24 (\% 15.1) "güçsüz", 21 (\% 13.2) "cinsel nesne", 21 (\% 13.2) "duygusal", 20 (\% 12.6) "bağımlı" olarak yansıtııırken hiçbir biçimde "çirkin", "cesur" ve "akıllı" olarak yansıtılmaması; prens karakterinin daha çok 21 (\% 12.5) "etkin", 20 (\% 12) "cesur", 19 (\% 11.3) "güçlü", 18 (\% 10.7) "baskın" olarak yansıtılırken daha az bir biçimde 0 (\% 0) "edilgen", 0 (\% 0) "güçsüz" ve 1 (\% 0.6) "işbirlikçi" olarak yansıtılması, kalıp bir biçimde yaşatılan toplumsal cinsiyet rollerinin yaşam boyu sürdürülebileceğini ortaya koymaktadır (Crisp ve Hiller, 2011; Kang, 1997; Taylor, 2003). Özellikle bu durum, sistemli eğitim kurumlarında öğrenin gören çocuklar ve öğretmen adaylarıyla karşılaştırıldığında hem çocuğun hem de yetişkinin birbirlerine tektipleştirilmiş tutum ve davranışlarla yaklaşmasına yol açabilir. Bu bakımdan, cinsiyet rollerine yönelik öğrenmelerin eleştirel bir bakış açısıyla sorgulanmasına gereksinim vardır.

Bu araştırmada ortaya çıkan sonuçlar, birçok farklı kültürde çocukluk yıllarından gençlik yıllarına kadar yapılan yaratıcı yazma ve toplumsal cinsiyete yönelik çalışmalardan (Gray-Schlegel ve Gray-Schlegel, 1995; Kanaris, 1999; Trepanier-Street, Romatowski ve McNair, 2009; Trepanier ve Romatowski, 1985; Trepanier-Street ve Romatowski, 1991; Tuck, Andree ve Bell, 1985) kültürel olarak bir fark olmadığını ortaya koymuştur. Yani, bu çalışmayla birlikte, Pennsylvania'da 4. ve 6. sınıfta okuyan 43 öğrenci üzerinde gerçekleştirilen çalışmada, her iki düzeyde bulunan öğrencilerin yazılarında erkek karakterler daha çok etkin rollerde gösterilirken kadın karakterler daha çok edilgen rollerde gösterilmiştir (Gray-Schlegel ve Gray-Schlegel, 1995). Melbourne'de 3. ve 4. sınıfta okuyan 29 kız ve 25 erkek olmak üzere 54 öğrenci üzerinde yapılan yazma çalışmasında, erkek ve kız öğrencilerin kendi cinsiyetlerini daha çok pekiştirecek sıfat, zamir ve eylem kullandıkları belirlenmiştir. Bununla birlikte, çalışmada, erkek öğrenciler, kendilerini olayın merkezinde olmak üzere benmerkezci bir biçimde birinci tekil kişi zamiriyle yazarken kız öğrenciler kendilerini olayın merkezinden uzaklaştırarak daha çok gözlemci bir biçimde yazmışlardır (Kanaris, 1999). Michigan'da 4. ve 6. sınıf 
düzeyinde 140 öğrenciden elde edilen 560 metin üzerinde yapılan çalışmada, erkek öğrenciler devingen, heyecanlı ve serüven dolu öykülerde saldırganlığa, cesur olmaya ve kahramanlığa yönelik ifade ve roller ortaya koyarken kız öğrenciler hemşirelik, bakıcılık gibi öykülerde korku, kaygı yaşayan, mutlu ve hoşgörülü olan ifade ve roller ortaya koymaktadırlar (Trepanier-Street ve ark., 2009). Missouri'de 5. ve 6. sınıf düzeyinde olan öğrencilerden elde edilen 84 öykü üzerinde yapılan çalışmada, erkek karakterlerin daha çok iddialı, kahraman, cesur, yetenekli ve özgür oldukları; kız karakterlerin ise terbiyeli, duygusal, bağımlı, edilgen ve açıklayıcı oldukları görülmüştür (Tuck ve ark., 1985). Bütün bu sonuçlar, yazma becerini geliştirilirken birçok farklı kültürde yer alan öğrencilerin yaş, cinsiyet ve sınıf düzeyi yönlerinden birbirlerinden farklı olmalarına karşın oluşturdukları karakterlere basmakalıp toplumsal cinsiyetçi roller yüklediklerini ortaya koymaktadır.

Bu araştırmanın ilk sınırlıı̆̆ı, salt 7 ile 37 yaş arasında yer alan katılımcılar üzerinde gerçekleştirilmiş olmasıdır. İlerleyen çalışmalarda, okulöncesi dönemi de kapsayacak bir biçimde görsel metinler üzerinden öğrencilerin toplumsal cinsiyet algılarını ortaya çıkartacak çalışmaların da yapılması gerekmektedir. İkinci olarak, bu araştırmada, öğrencilerin farklı düzeylerde yaratıcı yazma becerisiyle ortaya çıkan toplumsal cinsiyet algılarının ne kadar zaman daha devam ettiğinin bilinmemesi oluşturmaktadır. Bu konu üzerinden başka çalışmalarla takip çalışmalarının olduğu nitel çalışmalarının gerçekleştirilmesi de gerekmektedir. Üçüncü olarak, bu araştırmada, toplumsal cinsiyet algısı salt yaratııı yazma sürecinde ortaya çıkartılmaya çalışımıştır. Ilerleyen çalışmalarda, hem konuşma becerisini hem de öyküleyici ve bilgilendirici metinleri kapsayacak çalışmalar da yapılabilir. Son olarak, bu araştırmada, öğrencilerin sosyo-ekonomik düzeyleri dikkate alınmamıştır. Illerleyen çalışmalarda, sosyo-ekonomik düzey ile toplumsal cinsiyet algısı arasında ilişki olup olmadığını ortaya çıkartan araştırmalar da yapılabilir.

Sonuç olarak, bu çalışmada, farklı yaş ve cinsiyette bulunan öğrenci ve yetişkinlerin yaratıcı yazılarında verilen karakterlere yönelik yansıttıkları toplumsal cinsiyet anlayışlarının birbirlerine benzer oldukları ortaya çıkartılmıştır. Bu araştırmanın sonuçlarından yola çıkarak sunulabilecek öneri ise, yaratıcı yazma sürecinde, değerlendirme ölçekleriyle (Ben, 1993) toplumsal cinsiyet algısının ortaya çıkartıldığı deneysel çalışmaların yapılmasıdır.

\section{Kaynaklar}

Adıgüzel, Ö. (2010). Eğitimde Yaratıcı drama. Ankara: Naturel Yayıncılık.

Applebee, A. N. (2001). Alternative models of writing development. Roselmina Indrisano and James R. Squire (Eds.), Perspectives on writing research, theory, and practice. (pp. 90-112). USA: International Reading Association.

Arthur, B. \& Zell, N. A. (1996). Strategy for teaching creative writing skills to emotionally disturbed students, Preventing School Failure, 34(4), 26-31.

Beasley, C. (2005) Gender and sexuality: critical theories, critical thinkers. London: Sage. 
Bem, S. L. (1981). Gender schema theory: A cognitive account of sex typing. Psychological Review, 88, $354-364$.

Bem, S. L. (1993). The lenses of gender: Transforming the debate on sexual inequality. New Haven: Yale University Press.

Bigler, R. S., \& Liben, L. S. (2006). A developmental intergroup theory of social stereotypes and prejudice. Kail, R. V. (Ed.), Advances in child development and behavior (Vol. 34) (pp. 39-89). San Diego: Elsevier Academic Press.

Brookes, I., Marshall, M. (2004). Good writing guide. New York: Harap Publishers.

Buxton, A. E. (2011). Gender differences and writing development in kindergarteners. Master Dissertation, Oklahoma State University.

Cameron, D. (1999). Performing gender identity: Young men's talk and the construction of heterosexual masculinity. In A. Jaworski \& N. Coupland (Eds.), The discourse reader (pp. 443-458). London: Routledge.

Clark, E. (1995). Popular Culture Images of gender as reflected through young children's story. Annual Joint Meetings of the Popular Culture. Eric Document: 388966

Creswell, J. W. (2016). Araştırma deseni: Nitel, nicel ve karma yöntem yaklaşımları. Ankara: Eğiten-Kitap.

Croft, A., Schmader, T., Block, K., \& Baron, A. S. (2013). Actions speak loader than words: Parental beliefs, biases, and behaviors predict children's stereotypic preferences. Unpublished manuscript. Vancouver, BC: University of British Columbia.

Çer, E. (2016). Preparing for books children from birth to six: The approach of appropriateness for the child. Journal of Education and Practice, 7(6), 78-99.

Davies, B. (1993). Shards of glass: Children reading and writing beyond gendered identities. Cresskill: Hampton Press.

Demir, T. (2012). Türkçe eğitiminde yaratıcı yazma becerisini geliştirme ve küçürek öykü. Mustafa Kemal Üniversitesi Sosyal Bilimler Enstitüsü Dergisi, 9(19), 343-357.

Fabes, R. A., \& Eisenberg, N. (1996). Meta-analyses of age and sex differences in children's and adolescents' prosocial behaviour. W. Damon (Ed.), Handbook of Child Psychology. Arizona: Wiley.

Fleming, S. (1995). Whose stories are validated? Language Arts, 72(8), 590-596.

Göktürk, A. (1997). Sözün ötesi. İstanbul: Yapı Kredi Yayınları.

Graham, S., Perin, D. (2007). Writing next: Effective strategies to improve writing of adolescents in middle and high school. Washington: Alliance for Excellent Education.

Gray-Schlegel, M., \& Gray-Schlegel, T. (1995). An investigation of gender stereotypes as revealed through children's creative writing. Reading Research and Instruction, 35(2), 160-170.

Güleryüz, H. (2006). Yaratıcı çocuk edebiyatı. Ankara: PegemA Yayıncılık.

Hellinger, M., Bufimann, H. (2015). The linguistic representation of woman and men. M. Hellinger and $H$. Motschenbacher (Eds.), Gender and languages (pp. 1-27). Amsterdam: John Benjamin Publishing.

İpşiroğlu, Z. (2006). Yaratıcı yazma. İstanbul: Morpa Kültür Yayınları.

Kamler, B. (1993). The construction of gender in process writing classrooms. P. Gilbert (Ed.), Gender stories and the language classroom, (pp. 41-54). Victoria: Deakin University.

Kanaris, A. (1999). Gendered journeys: Children's writing and the construction of gender. Language and Education, 13(4), 254-268.

Kavcar, C., Oğuzkan, F., \& Hasırcı, S. (2016). Türkçe öğretimi, Türkçe ve sınıf öğretmenleri için. Ankara: Anı Yayıncılık.

Kinzie, M (1999). A poet's guide to writing poetry. Chicago: Chicago University Press. 
Leaper, C. (1994). Exploring the consequences of gender segregation on social relationships. Leaper, C. (Ed.), Childhood gender segregation: causes and consequences (pp. 67-86). San Francisco: Jossey-Bass.

Leaper, C., \& Smith, T. E. (2004). A meta-analytic review of gender variations in children's language use: Talkativeness, affiliative speech, and assertive speech. Developmental psychology, 40(6), 993.

Llosa, M. V. (2012). Genç bir romancıya mektuplar. (Çev.: Emrah İnce). İstanbul: Can Yayınları.

Maccoby, E. E. (1990). Gender and relationships: A developmental account. American psychologist, 45(4), 513.

Macionis, J. J. (2015). Sociology. USA: Pearson Higher.

Maltepe, S. (2006). Yaratıcı yazma yaklaşımı açısından Türkçe derslerindeki yazma süreçlerinin ve ürünlerinin değerlendirilmesi. Ankara: Ankara Üniversitesi Sosyal Bilimler Enstitüsü, Yayımlanmamış Doktora Tezi.

Martin, C. L., \& Ruble, D. N. (2004). Children's search for gender cues: cognitive perspectives on gender development. Current Directions in Psychological Science, 13, 67-70.

Martin, C. L., Fabes, R. A., Hanish, L., Updegraff, K., Miller, C., Gaertner, B., Kochel, K., \& Foster, S.(2012). The Sanford Harmony Program: Program description and preliminary findings. Invited address presented at the Gender Development Research Conference, San Francisco.

Mayesky, M. (1995). Creative activities for young children. USA: Delmar Publishers.

McAuliffe, S. (1994). Toward understanding one another: Second graders' use of gendered language and story styles. The Reading Teacher, 47(4), 302-310.

McCabe, J., Fairchild, E., Grauerholz, L., Pescosolido, B. A., \& Tope, D. (2011). Gender in twentieth-century children's books: Patterns of disparity in titles and central characters. Gender \& society, 25(2), 197-226.

McVey, D. (2008). Why all writing is creative writing. Innovations in Education and Teaching International, 45(3), 289-294.

Mehta, C. M., \& Strough, J. (2010). Gender segregation and gender-typing in adolescence. Sex Roles, 63, 251263.

Millard, E. (1997). Differently literate: Gender identity and the construction of the developing reader. Gender and Education, 9(1), 31-48.

Morley, D. (2007). The Cambridge introduction to creative writing. Cambridge: Cambridge University Press.

Myers, D. G. (1993). The rise of creative writing. Journal of the History of Ideas, 54(2), 277-297.

Nickerson, R. S., Perkins, D. N., \& Smith, E. E. (1985). The teaching of thinking. Hillsdale: Erlbaum.

Oral, G. (2003). Yine yazı yazıyoruz. Ankara: PegemA Yayıncılık.

Özdemir, E., Binyazar, A. (1979). Yazmak sanatı, kompozisyon. Ankara: Varlık Yayınevi.

Peterson, S. (2001). Gender identities and self-expression in classroom narrative writing. Language Arts, 78(5), 451-457.

Ramet, A. (2007). Creative writing: How to unlock your imagination, develop your writing skills and get published. UK: How to Books Ltd.

Russell, A., Hart, C. H., Robinson, C. C., \& Olsen, S. F. (2003). Children's sociable and aggressive behaviour with peers: a comparison of the United States and Australia, and contributions of temperament and parenting style. International Journal of Behavioural Development, 27, 74-86.

Sampson, F. (2004). Creative writing in health and social care. London: Jessica Kingsley.

San, i. (2008). Sanat ve eğitim, yaratıcılık, temel sanat kuramları, sanat eleştirisi yaklaşımları. Ankara: Ütopya Yayınevi. 
Serbin, L. A., Moller, L. C., Gulko, J., Powlishta, K. K., \& Colburne, K. A. (1994). The emergence of gender segregation in toddler playgroups. Leaper, C. (Ed.), Childhood gender segregation: causes and consequences. New directions for child development, No. 65 (pp. 7-17). San Francisco: Jossey-Bass.

Sever, S. (2004). Türkçe öğretimi ve tam öğrenme. Ankara: Anı Yayıncılık.

Sharp, C. (2004). Developing Young children's creativity: What can we learn from research? Topic, 32, 1-12.

Sharples, M. (1999). How we write: Writing as creative desing. London: Routledge

Shuman, R.B. (1995). Gender differences. Educational Leadership, 49(7), 86.

Spear, M.G. (1989). Differences between the written work of boys of girls. British Educational Research Journal, 15, 271-277.

Steele, C. M., Spencer, S. J., \& Aronson, J. (2002). Contending with group image: the psychology of stereotype and social identity threat. Zanna, M. P. (Ed.), Advances in experimental social psychology (Vol. 34) (pp. 379-440). New York: Academic Press.

Striker, S. (2005). Çocuklarda sanat eğitimi. İstanbul: Epsilon Yayınevi.

Stuart, M. (2005). What price inclusion? G. Layer (Ed.), Closing the equity gap: The impact of widening participation strategies in the UK and the USA (p. 166). Leicester: NIACE.

Susar Kırmızı, F., \& Beydemir, A. (2012). Illköğretim 5. sınıf Türkçe dersinde yaratıcı yazma yaklaşımının yazmaya yönelik tutumlara etkisi. Ahi Evran Üniversitesi Kırşehir Eğitim Fakültesi Dergisi, 13(3), 319-337.

Temizkan, M. (2010). Türkçe öğretiminde yaratıcı yazma becerilerinin geliştirilmesi. TÜBAR, XXVII, 621-643.

Tepper, C. A., \& Cassidy, K. W. (1999). Gender differences in emotional language in children's picture books. Sex Roles, 40(3-4), 265-280.

Thomson, L. (2013). Learning to teach creative writing. Changing English, 20(1), 45-52.

Trepanier, M. L., \& Romatowski, J. A. (1985). Atttibutes and roles assigned to characters in children's writing: Sex differences and sex-role perceptions. Sex Roles, 13(5/6), 263-271.

Trepanier-Street M. L., Romatowski, J. A., \& McNair, S. (2009). Children's written responses to stereotypical and non-stereotypical story starters. Journal of Research in Childhood Education, 5(1), 60-72.

Trepanier-Street, M., \& Romatowski, J. A. (1991). Achieving sex equity goals: Implications from creative writing research. Educational Horizons, 70(1), 34-40.

Tuck, D. L., Andree, B. V., \& Bell, M. I. (1985). Analysis of sex stereotyping in characters created by young authors. The Journal of Educational Research, 78(4), 248-253.

Tyre, P. (2008). The trouble with boys: A surprising report card on our sons, their problems at school, and what parents and educators must do. New York: Crown Publishers.

Üstündağ, T. (2002). Yaratıcılığa yolculuk. Ankara: PegemA Yayıncılık.

Vass, E., Littleton, K., Miell, D., Jones, A. (2008). The discourse of collaborative creative writing: Peer collaboration as a context for mutual inspiration. Thinking Skills and Creativity, 3(3), 192-202.

White, J. (1990). On literacy and gender. F. Christie (Ed.), Literacy for a changing world. (pp. 143 -166). Hawthorn: Australian Council for Educational Research.

Winstead, B. A., Derlega, V. J., \& Unger, R. K. (1999). Sex and gender. V. J. Derlega, B. A. Winstead, \& W. H. Jones (Eds.), Personality: Contemporary theory and research (pp. 257-281). Chicago: Nelson-Hall.

Woolf, F., \& Belloni, J. (2005). Reflect and Review: The Arts and Creativity in Early Years. England: Arts Council.

Yıldırım, A. ve Şimşek, H. (2011). Sosyal bilimlerde nitel araştırma yöntemleri. Ankara: Seçkin Yayıncılık.

Yıldırım, R. (2003). Yaratıcılık ve yenilik. İstanbul: Sistem Yayıncılık. 